\title{
PELATIHAN PENULISAN ARTIKEL ILMIAH DAN PUBLIKASI JURNAL ILMIAH BAGI GURU-GURU DI KABUPATEN TUBAN
}

\author{
Mu'jizatin Fadiana, Warli, Heny Sulistyaningrum, Puji Rahayu, Rita \\ Yuliastuti \\ Universitas PGRI Ronggolawe Tuban \\ mujizatin000@gmail.com,warli66@gmail.com, \\ henysulityaningrum.65@gmail.com, pujirahayu.mpd@gmail.com
}

\begin{abstract}
This community service activity is motivated by the low ability of teachers to write scientific papers. The purpose of the activity is to increase the ability of teachers to compile scientific articles based on Classroom Action Research (CAR). The method of this activity is in the form of training and mentoring to participants. Training is carried out online through the zoom application, while mentoring is also carried out online through the Telegram Group application. This activity is carried out through 4 stages, including; the preparation stage, the implementation stage, the assistance stage, and the evaluation stage. Instruments to measure the success of the training process and results using questionnaires and evaluation sheets. Based on the data from the community service results, it can be concluded that the knowledge of teachers about writing scientific papers, publication of scientific papers and teacher professionalism has increased. This can be proven by the success of teachers in publishing scientific articles. And there is an effective cooperative relationship between the MGMP and the Mathematics education program FKIP, PGRI Ronggolawe University, Tuban.
\end{abstract}

Keywords: Writing scientific articles, Publications, Classroom Action Research 


\begin{abstract}
ABSTRAK
Kegiatan pengabdian masyarakat ini dilatar belakangi oleh masih rendahnya kemampuan menulis karya ilmiah pada guru-guru. Tujuan kegiatan adalah meningkatkan kemampuan guru-guru dalam menyusun artikel ilmiah berbasis Penelitian Tindakan Kelas (PTK). Metode kegiatan ini berupa pelatihan dan pendampingan kepada peserta. Pelatihan dilaksanakan dalam jaringan (daring) melalui aplikasi zoom, sedangkan pendampingan juga dilaksanakan daring melalui aplikasi Grup Telegram. Kegiatan ini dilaksanakan melaui 4 tahap, meliputi; tahap persiapan, tahap pelaksanaan, tahap pendampingan, dan tahap evaluasi. Instrumen untuk mengukur keberhasilan proses dan hasil pelatihan menggunakan angket dan lembar evaluasi. Berdasarkan data hasil pengabdian masyarakat dapat disimpulkan bahwa pengetahuan guru-guru tentang penulisan karya tulis ilmiah, publikasi karya ilmiah dan profesionalisme guru mengalami peningkatan. Hal ini dapat dibuktikan dari keberhasilan guru dalam mempublikasikan artikel ilmiah. Serta terjalin hubungan kerjasama yang efektif antara Musyawarah Guru Mata pelajaran (MGMP) Matematika SMK Kabupaten Tuban dan prodi pendidikan matematika FKIP Universitas PGRI Ronggolawe Tuban.
\end{abstract}

Kata Kunci: Penulisan artikel Ilmiah, Publikasi, PTK 


\section{A. PENDAHULUAN}

Salah satu isi standar kompetensi pedagogik dan profesional guru kelas maupun guru mata pelajaran (mapel) adalah guru berkewajiban melakukan tindakan reflektif (PTK) untuk peningkatan kualitas pembelajaran dan pengembangan keprofesian secara berkelanjutan melalui tindakan reflektif. Hal ini sebagaimana tertuang dalam Permendiknas No 16 Tahun 2007 tentang Standar Kualifikasi Akademik dan Kompetensi Guru. Upaya untuk meningkatkan kompetensi guru terus dilakukan salah satunya melalui Pengembangan Keprofesian Berkelanjutan (PKB). PKB menurut Permenegpan dan Reformasi Birokrasi Nomor 16 Tahun 2009 Tentang Jabatan Fungsional Guru dan Angka Kreditnya, merupakan pengembangan kompetensi guruyang dilaksanakan sesuai dengan kebutuhan, bertahap, berkelanjutan untuk meningkatkan profesionalitasnya. Secara umum tujuan dari PKB adalah untuk meningkatkan kualitas layanan pendidikan di sekolah dalam rangka meningkatkan mutu pendidikan. Sedangkan tujuan khususnya adalah memfasiltasi guru untuk mencapai standar kompetensi profesi yang telah ditetapkan, memfasilitasi guru untuk terus memutakhirkan kompetensi yang merekamiliki sekarang dengan apa yang menjadi tuntutan ke depan berkaitan dengan profesinya, memotivasi guruguru untuk tetap memiliki komitmen melaksanakan tugas pokok dan fungsinya sebagai tenaga professional, mengangkat citra, harkat, martabat profesi guru, rasa hormat dan kebanggaan kepada penyandang profesi guru.

Salah satu unsur PKB yang berkaitan dengan kewajiban guru adalah melakukan tindakan reflektif melalui PTK untuk peningkatan kualitas pembelajaran. Angka kredit akan diberikan jika guru menulis artikel ilmiah dan melakukan publikasi ke dalam jurnal ilmiah. Terdapat beberapa kompetensi yang harus dikuasai oleh guru untuk bisa menyusun artikel 
ilmiah. Kompetensi tersebut antara lain; pemahaman tentang hakikat karya ilmiah, pengetahuan tentangkaidah berbahasa Indonesia yang baik dan benar, memiliki wawasan luas tentang pendidikan dan pembelajaran, baik teoretik maupun praktik melalui berbagai sumber referensi serta pengalaman profesionalnya sebagai guru, pemahaman mengenai metode penelitian serta menguasai materi bidang keilmuannya (Kemendiknas, 2010).

Hasil penelitian Mawardi (2012) menyatakan bahwa PKB sebagai wadah pengembangan keprofesian guru yang diharapkan dapat meningkatkan martabat dan citra profesi guru belum memadai, paling tidak jika diukur dari kelancaran dalam peningkatan jenjang karier jabatan guru. Pendapat ini sejalan dengan fakta yang kami temukan pada guru-guru SMK di Kabupaten Tuban. Berdasarkan informasi dari ketua MGMP Matematika SMK Kabupaten Tuban, bahwa kenaikan pangkat guru mengalami kendala disebabkan kurang terpenuhinya angka kredit nilai pengembangan diri yang diajukan. Kebanyakan dari mereka belum dapat mempublikasikan karya tulis, yang menjadi salah satu syarat memenuhi angka kredit. Sementara itu, beberapa pendapat menyatakan bahwa penyebab berhentinya karier guru disebabkan oleh karena kompetensi guru dalam memenuhi komponen publikasi ilmiah yang masih sangat rendah (Sujianto, 2013; Sunardi, 2013).

Permasalahan yang dihadapi oleh mitra, dalam hal ini adalah MGMP Matematika SMK Kabupaten Tuban, adalah rendahnya kemampuan menulis karya ilmiah dalam bentuk artikel ilmiah di kalangan guru-guru matematika dari berbagai sekolah, baik SMK Negeri maupun SMK Swasta. Syarat menulis karya ilmiah menjadi penghambat kenaikan jenjang pangkat bagi guru. Penulisan karya Ilmiah selain menjadi syarat bagi pengembangan karir, menulis juga menjadi sarana bagi pengembangan diri seorang guru. Guru tidak hanya dituntut mengajar dan membuat administrasi saja tetapi pengembangan diri guru juga menjadi penting dalam meningkatkan kualitas 
pengajaran. Menulis adalah salah satu unsur literasi selain membaca. Guru harus meningkatkan kemampuan literasi, karena nantinya guru akan membimbing siswa untuk meningkatkan kemampuan literasinya.

Kegiatan pengabdian masyarakat ini bertujuan untuk memberikan solusi dari permasalahan yang sedang dihadapi mitra, yaitu rendahnya kemampuan menulis karya tulis ilmiah dalam bentuk artikel ilmiah, sekaligus dalam rangka peningkatan kompetensi pendidik, khususnya bagi guru-guru mapel matematika jenjang SMK di Kabupaten Tuban. Selain pendampingan penulisan artikel ilmiah, kegiatan ini juga memberikan pelatihan pada peserta untuk publikasi pada jurnal ilmiah nasional. Sehingga diharapkan peserta tidak hanya terampil menulis artikel ilmiah, namun juga mempublikasikan artikel ilmiahnya untuk disebarluaskan dan dibaca oleh orang lain. Kegiatan pengabdian masyarakat yang telah dilakukan merupakan kerjasama antara prodi pendidikan matematika Fakultas Keguruan dan Ilmu Pendidikan (FKIP) Universitas PGRI Ronggolawe Tuban dengan Musyawarah Guru Mata Pelajaran (MGMP) Matematika jenjang SMK di Kabupaten Tuban.

\section{B. PELAKSANAAN DAN METODE}

Metode kegiatan ini berupa pelatihan dan pendampingan kepada guruguru matematika SMK di Kabupaten Tuban yang tergabung dalam Musyawarah Guru Mata Pelajaran Matematika. Pelatihan dilaksanakan dalam jaringan (daring) melalui aplikasi zoom, sedangkan pendampingan juga dilaksanakan daring melalui aplikasi Grup Telegram . Kegiatan ini dilaksanakan melaui 4 tahap,meliputi; tahap persiapan, tahap pelaksanaan, tahap pendampingan, dan tahap evaluasi.

Pada tahap persiapan meliputi penyusunan materi dan instrumen kegiatan pengabdian kepada masyarakat dan berkoordinasi dengan ketua MGMP matematika SMK. Selanjutnya tahap kedua adalah pelaksanaan, 
yaitu tim pengabdian melaksanakan kegiatan pengabdian pada masyarakat. Setelah tahap pelaksanaan, dilanjutkan dengan tahap pendampingan. Pada tahap pendampingan, tim memberikan pendampingan kepada peserta untuk menyusun artikel ilmiah berbasis pada hasil Penelitian Tindakan Kelas (PTK) yang telah dilakukan. Selain itu, tim juga mendampingi peserta hingga publikasi artikelnya pada jurnal ilmiah nasional. Tahap terakhir adalah tahap evaluasi berupa umpan balik dari perwakilan guru dan pihak terkait. Evaluasi dari kegiatan pengabdian ini akan dilaksanakan melalui refleksi dan masukan dari peserta pada saat berakhirnya kegiatan. Komponen yang dinilai dalam pelatihan adalah angket respon peserta pelatihan dan atikel ilmiah yang disusun. Secara ringkas metode kegiatan pengabdian masyarakat dapat dilihat pada gambar 1 .

\section{Gambar 1.}

Tahapan Pengabdian Masyarakat

\begin{tabular}{|c|c|c|c|}
\hline Tahap & Tahap & Tahap & Tahap \\
\hline & & 1 & i \\
\hline $\begin{array}{l}\text { - Koordinasi } \\
\text { dengan ketua } \\
\text { MGMP } \\
\text { Matematika } \\
\text { SMK } \\
\text { - Menyusun } \\
\text { materi dan } \\
\text { instrumen } \\
\text { kegiatan }\end{array}$ & $\begin{array}{l}\text { - Pelatihan menulis } \\
\text { artikel ilmiah } \\
\text { - Pelatihan publikasi } \\
\text { artikel ilmiah pada } \\
\text { jurnal ilmiah } \\
\text { nasional }\end{array}$ & $\begin{array}{l}\text { - Pendampingan } \\
\text { menulis artikel } \\
\text { ilmiah } \\
\text { - Pendampingan } \\
\text { memilih jurnal yang } \\
\text { relevan dan submit } \\
\text { artikel ilmiah pada } \\
\text { jurnal }\end{array}$ & $\begin{array}{l}\text { - Meminta refleksi } \\
\text { dan masukan dari } \\
\text { peserta melalui } \\
\text { angket respon } \\
\text { - Artikel ilmiah yang } \\
\text { berhasil publikasi }\end{array}$ \\
\hline
\end{tabular}

\section{HASIL DAN PEMBAHASAN}

Kegiatan pengabdian masyarakat ini dilaksanakan pada tanggal 21-22 Desember 2020. Sebelumnya diawali dengan persiapan. Adapun paparan kegiatan yang dilaksanakan setiap tahapan adalah sebagai berikut 1. Tahap Persiapan 
Pada tahap persiapan, tim berkoordinasi dengan ketua MGMP Matematika SMK Kabupaten Tuban tentang instrument pengabdian, materi pelatihan, waktu dan setting kegiatan pengabdian yang akan dilaksanakan. Berdasarkan hasil koordinasi, tim menyusun materi pelatihan. Materi pelatihan terdiri atas dua materi, yaitu; penulisan artikel ilmiah dan pengenalan jurnal ilmiah serta publikasi artikel ilmiah pada jurnal.Perancangan materi ini dikaji disesuaikan dengan kebutuhan mitra berdasarkan hasil diskusi antara timpengabdian dengan MGMP Matematika SMK. Selain menyiapkan materi, tim juga menyusun jadwal pelatihan. Adapun susunan jadwal pelatihan adalah sebagai berikut

Tabel 1.

Jadwal Pelatihan Penulisan Artikel Ilmiah

\begin{tabular}{|c|c|c|c|}
\hline Hari/Tanggal & Waktu & Materi & Narasumber \\
\hline \multirow{6}{*}{$\begin{array}{l}\text { Senin / } \\
21 \text { Desember } \\
2020\end{array}$} & $08.00-08.30$ & Pembukaan & Panitia \\
\hline & & & \\
\hline & & & \\
\hline & $08.30-10.30$ & Penulisan & Warli, \\
\hline & $10.30-11.30$ & Ilmiah & M.Pd \\
\hline & & Diskusi dan Sharing & \\
\hline \multirow{6}{*}{$\begin{array}{ll}\text { Selasa / } 22 \\
\text { Desember } \\
2020\end{array}$} & $08.30-09.30$ & $\begin{array}{ll}\text { Pengenalan jurnal } \\
\end{array}$ & Dr. Mu'jizatin \\
\hline & & ilmiah nasional dan & Fadiana, M.Pd \\
\hline & $09.30-10.30$ & internasional & \\
\hline & & Publikasi & \\
\hline & $10.30-11.30$ & jurnal ilmiah & \\
\hline & & Diskusi dan Sharing & \\
\hline
\end{tabular}

2. Tahap Pelaksanaan

Tim pelaksana pengabdian melaksanakan kegiatan secara dalam jaringan (daring) dengan menggunakan platform zoom. Peserta kegiatan ini adalah 36 orang, dari guru-guru matematika perwakilan SMK di Kabupaten Tuban. Pemateri pada hari pertama adalah Bapak Dr Warli, 
M.Pd yang mempresentasikan materi tentang komponen artikel ilmiah hasil penelitian. Materi disampaikan dalam bentuk power point (PPT). Komponen artikel ilmiah hasil penelitian terdiri atas; (1) Judul, (2) Penulis, (3) Abstrak \& Kata Kunci, (4) Pendahuluan, (5) Metode, (6) Hasil, (7) Pembahasan, (8) Simpulan, dan (9) Daftar Rujukan. Tiap-tiap komponen artikel ilmiah tersebut dijelaskan oleh pemateri secara jelas dan detail.Untuk memudahkan pemahaman peserta pelatihan, pemateri memberikan penjelasan bahwa secara populer, sistematika paparan isi artikel hasil penelitian biasa dikelompokkan dalam akronim IMRaD (Introduction, Method, Result, and Discussion). Adapun kualitas rujukan ditandai dengan terpenuhinya tiga kriteria: relevansi dengan bidang ilmu yang diteliti, kemutakhiran sumber pustaka (minimal $80 \%$ terdiri atas pustaka yang terbit 10 tahun terakhir), dan keprimeran, sebaiknya yang dimuat dalam jurnal bereputasi (minimal jumlahnya 80\%).

Kegiatan pemaparan materi disampaikan oleh pemateri diselingi dengan sesi tanya jawab dan diskusi dengan para peserta. Pemateri juga meminta data dari peserta berupa judul penelitian yang pernah dilakukan oleh mereka. Para peserta menuliskan judul PTK mereka. Peserta pelatihan membuat draft judul artikel, nama penulis, menentukan kata kunci dalam abstrak dan kerangka pendahuluan serta mendiskusikan draft tersebut dengan pemateri. Pemateri juga memberikan contoh sebuah artikel yang sudah dipublikasikan dan membedah artikel tersebut menurut urutan komponen sebuah artikel ilmiah.Kegiatan ini bertujuan untuk memberikan penjelasan dan latihan yang lebih konkrit tentang bagaimana menuliskan hasil penelitian dalam bentuk artikel ilmiah. 
Gambar 2.

Pemaparan Via Zoom tentang Penulisan Artikel Ilmiah

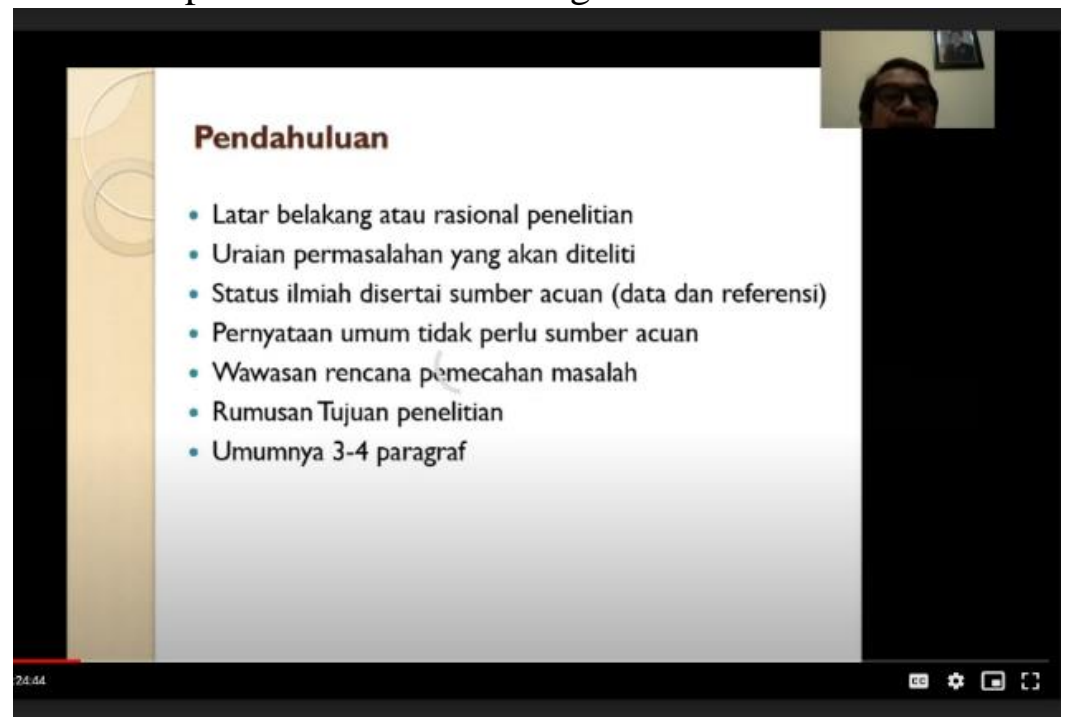

Selanjutnya, pada hari kedua, pemateri memberikan penjelasan tentang rumah jurnal dan tujuan dari penerbitan sebuah jurnal. Adapun tujuan menerbitkan jurnal yaitu untuk meregistrasi kegiatan kecendekiaan, menyertifikasi hasil kegiatan yang memenuhi persyaratan ilmiah, mendiseminasikannya secara meluas kepada khalayak ramai, dan mengarsipkan semua temuan hasil kegiatan kecendekiaan ilmuwan yang dimuatnya. Pemateri juga menginformasikan tentang rumah jurnal yang dimiliki oleh Universitas PGRI Ronggolawe. Pemateri juga menjelaskan ke peserta pelatihan bagaimana untuk registrasi ke jurnal tersebut agar bisa login, submit artikel dan lain-lain. Informasi tentang jurnal nasional terakreditasi SINTA (rangking 1-6), DOAJ, journal internasional terindeks Scopus (Q1-Q4), dan lembaga pengindeks lainnya juga diberikan kepada para peserta dengan tujuan memberikan wawasan kepada mereka tentang rumah jurnal untuk publikasi karya tulis ilmiah. 
Setelah pemaparan materi dan diskusi dilaksanakan, para peserta mulai memahami bagaimana cara menulis artikel ilmiah sesuai dengan kaedah dan mereka juga mengetahui bagaimana melakukan proses publikasi mulai dari registrasi dan membuat akun di sebuah jurnal, login ke jurnal dan mengirim artikel untuk publikasi.

\section{Gambar 3.}

Pemaparan via Zoom tentang Pengenalan jurnal ilmiah nasional dan internasional
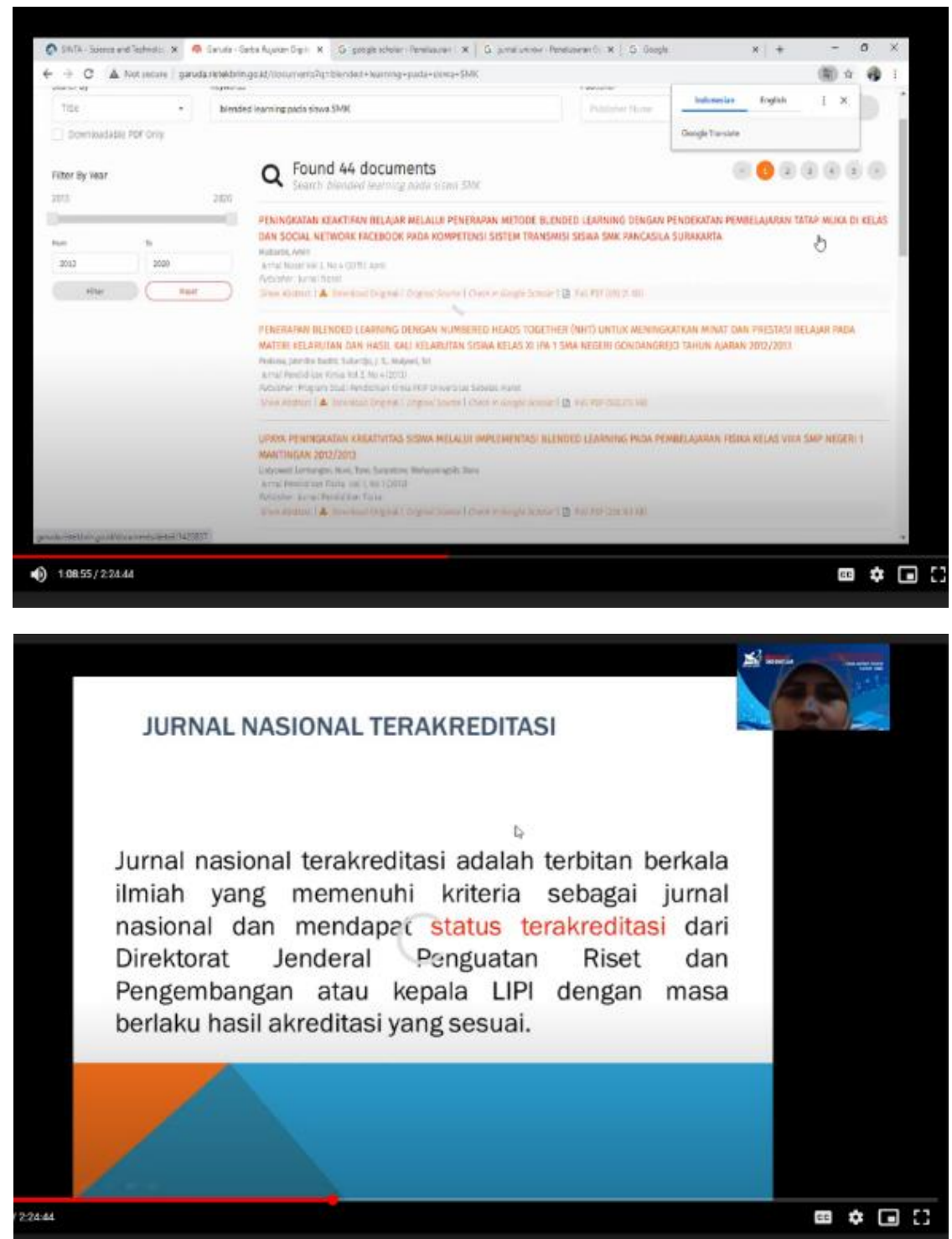
3. Tahap Pendampingan

Kegiatan yang dilakukan pada tahap pendampingan adalah tim mendampingi peserta dalam menulis artikel ilmiah hasil dari PTK yang telah dilakukan. Pendampingan dilakukan secara daring melalui grup Whatsapp. Peserta berkonsultasi pada dosen untuk menyusun artikel ilmiah berdasrkan draft yang telah dibuat pada pertemuan pertama pada saat pelatihan.

4. Tahap Evaluasi

Pada akhir kegiatan pelatihan, diberikan angket yang berisikan 8 (delapan) butir pertanyaan dan rekapitulasi hasilnya sebagai bahan masukan perbaikan untuk rencana kegiatan pengabdian masyarakat di tahun mendatang. Selanjutnya kepada peserta diberi kesempatan untuk mendapatkan pendampingan dari tim dosen untuk penyusunan artikel ilmiah berbasis PTK. Pendampingan dilakukan melalui grup telegram dan pendampingan secara tatap muka. Artikel ilmiah yang sudah selesai disusun.

\section{KESIMPULAN}

Berdasarkan hasil analisis instrumen evaluasi dan berpijak pada tujuan kegiatan pelatihan dapat disimpulkan bahwa pengetahuan para guru-guru tentang penulisan karya tulis ilmiah mengalami peningkatan; keterampilan dalam menulis karya ilmiah mengalami peningkatan terbukti dari sejumlah artikel yang berhasil dipublikasikan; profesionalisme guru mengalami peningkatan terbukti berhasil menulis artikel ilmiah; dan terjalin hubungan kerjasama yang saling efektif antara MGMP Matematika SMK dan prodi pendidikan matematika FKIP Universitas PGRI Ronggolawe Tuban, terbukti kegiatan pelatihan berjalan lancar. 
Saran bagi kegiatan pengabdian kepada masyarakat bagi Prodi Pendidikan Matematika adalah: 1) memperbaiki beberapa aspek khususnya aspek waktu dalam penyelengaraan kegiatan pelatihan, 2) memperluas kerjasama antara Prodi Pendidikan Matematika dengan mitra yang lain, 3) Meningkatkan motivasi guru-guru dalam menulis artikel karya ilmiah, 4) Meningkatkan motivasi guru untuk lebih banyak mempublikasikan hasil karya tulis ilmiah. 


\section{DAFTAR PUSTAKA}

Afandi, M. H., Arifin, Z., Saikhon, M., \& Ramdhan, T. W. (2021). Community Empowerment Efforts Through Collecting Coin Funds in Ngronggot Village, Ngronggot District, Nganjuk Regency. Jurnal Pengabdian Al-Ikhlas Universitas Islam Kalimantan Muhammad Arsyad Al Banjary, 6(3).

Kemendiknas. 2010. Pembinaan dan Pengembangan Profesi Guru Buku 4 -

Pedoman Kegiatan Pengembangan Keprofesian Berkelanjutan (PKB) dan angka Kreditnya. Jakarta: Kemendiknas -PMPTK.

Mashudi, M., Suparyanto, D., \& Arisandi, B. (2020). Pendayagunaan Potensi

Ekonomi Desa Paterongan Kecamatan Galis Melalui KKN Mahasiswa STAIDHI Tahun 2020. Dharma: Jurnal Pengabdian Masyarakat, 1(1), 1-16.

Mawardi. 2012. Kebijakan Pengembangan Keprofesian Berkelanjutan (PKB)

dan Kewajiban Memenuhi Jam Mengajar: Sebuah Kebijakan

Dilematis?. Scholaria: Jurnal Pendidikan dan Kebudayaan, 2(1), 91115.

Sujianto. 2013. Pengembangan Profesionalitas Berkelanjutan/Continuing Professio nality Development (CPD) Guru Bersertifikat Pendidik di

SMK Rumpun Teknologi se-Malang Raya. Malang: Pendidikan

Kejuruan-Pascasarjana Universitas Negeri Malang.

Sunardi. 2013. Guru dan Perubahan Jaman (Menulis Untuk Lulus atau Stagnan Sehingga “Mati Alus").Widya Sari. 15(1) : 98-105. 